\title{
Introduced fish in Pyrenean high mountain lakes: impact on amphibians and other organisms, and conservation implications
}

\author{
Alexandre Miró* and Marc Ventura \\ Centre for Advanced Studies of Blanes, Spanish Research Council (CEAB-CSIC), Integrative Freshwater \\ Ecology Group (IFE), Accés a la Cala St. Francesc, 14, Blanes 17300, Girona, Catalonia, Spain. \\ * Corresponding author: alexestanys@gmail.com
}

Received: $14 / 11 / 18 \quad$ Accepted: 08/07/19

\begin{abstract}
Introduced fish in Pyrenean high mountain lakes: impact on amphibians and other organisms, and conservation implications
\end{abstract}

Pyrenean high mountain lakes are naturally fishless due to hydrographic barriers that have prevented the natural colonisation of fish species from lower elevation streams. However, there have been numerous introductions of trout and minnows to such ecosystems, either in historical and recent periods. Trout and minnow introductions can cause large ecological problems and ecosystem changes in high mountain lakes, since both taxa occupy the top of a lake's food web. The study had two objectives. First, we wanted to investigate which particular anthropogenic and environmental factors best explained fish presence in the Pyrenean lakes. For that purpose we collected data on trout and minnow occurrence from 520 high mountain lakes $>0.5$ ha in the southern Pyrenees. The second objective was to investigate the effect of introduced fish on several groups of organisms such as amphibians, conspicuous macroinvertebrates, planktonic crustaceans and littoral epilithic community. For that purpose we sampled 1736 lakes and ponds at different levels of intensity. The distribution of Salmo trutta in the lakes of the southern slopes of the Pyrenees was best explained by both anthropogenic factors and lake characteristics, while only anthropogenic factors linked to recreational fishing were associated with the distribution of the exotic trout Salvelinus fontinalis and Oncorhynchus mykiss. In the case of minnow occurrence, previous presence of trout in the lake was the most explanative variable, confirming its association with its use as live-bait in recreational fishing. Fish presence was linked with the disappearance of most amphibian species. Despite fish had a high local effect, at Pyrenean range scale, western-eastern patterns of some environmental variables were the main drivers of amphibian species distribution. Minnows also showed a sizeable impact on the pelagic habitat, reducing the occurrence of some crustacean zooplankton species that appeared to be unaffected by trout. In addition, we confirmed the presence of a littoral trophic cascade that defines most of the characteristics of the littoral epilithon of Pyrenean high mountain lakes and ponds through fish predation of tadpoles and hence, by a drastic reduction of grazing activity.

Key words: Alpine lakes, epilithon, invasive fish, invasive species, macroinvertebrates, planktonic crustaceans

\section{RESUMEN}

Los peces introducidos en lagos de alta montaña de los Pirineos: impacto sobre los anfibios y otros organismos, e implicaciones para la conservación

Los lagos de alta montaña de los Pirineos están libres de peces de forma natural, debido a las barreras hidrográficas que impiden su colonización. Sin embargo, se han producido numerosas introducciones de truchas y piscardos en estos ecosistemas, tanto en periodos históricos como recientes. Estas introducciones causan cambios en el ecosistema y problemas ecológicos, ya que ambos peces ocupan la cúspide de la red alimentaria. Este estudio tenía dos objetivos. Primero, investigamos qué factores antropogénicos y ambientales explican la presencia de peces en los lagos de los Pirineos. Para ello, recopilamos datos sobre la ocurrencia de truchas y piscardos en 520 lagos de alta montaña $>0.5$ ha en la vertiente sur del Pirineos. El segundo objetivo fue investigar el efecto de los peces introducidos sobre distintos grupos de organismos: anfibios, macroinvertebrados conspicuos, crustáceos planctónicos y la comunidad epilítica litoral. Para abordar el segundo objetivo muestreamos 1736 lagos, lagunas y charcas a diferentes niveles de intensidad. La distribución de Salmo trutta en los lagos de la vertiente 
sur de los Pirineos se explica principalmente por los factores antropogénicos y las características del lago, mientras que solo los factores antropogénicos relacionados con la pesca deportiva se asociaron con la distribución de las truchas exóticas Salvelinus fontinalis $y$ Oncorhynchus mykiss. En el caso de la ocurrencia de piscardos (Phoxinus sp.), la presencia previa de truchas en el lago fue la variable más explicativa, confirmando la asociación con la pesca deportiva con cebo vivo. La presencia de peces estuvo relacionada con la desaparición de la mayoría de las especies de anfibios. En el caso de los anfibios, aunque los peces introducidos tuvieron un alto impacto local, los patrones este-oeste de algunas variables ambientales emergieron como los principales factores que condicionan el área de distribución de los anfibios a escala pirenaica. El piscardo también mostró un impacto considerable en el hábitat pelágico, reduciendo la abundancia de algunas especies de crustáceos planctónicos que parecían no verse afectadas por las truchas. Además, confirmamos la presencia de una cascada trófica litoral mediada por la depredación de peces sobre renacuajos, que condiciona la mayoría de las características del epiliton litoral mediante la drástica reducción del herbivorismo.

Palabras clave: crustaceos planctónicos, epiliton, especies invasoras, lagos alpinos, macroinvertebrados, peces invasores

\section{INTRODUCTION}

Several anthropogenic stressors have been identified worldwide as major conservation threats in aquatic and terrestrial ecosystems. These include habitat destruction and fragmentation, introduction of invasive species, land-use changes, pollution, human population growth, overharvesting and climate change (Brook et al., 2008). Amongst them, the impact of multiple species invasions on native organisms and communities can be difficult to interpret, because invaders can interact among themselves and affect native species in several ways (Simberloff, 2006). In general, ecological factors do not function individually, and an ecosystem's integrity is often affected by complex interactions from multiple stressors and environmental variables (e.g. Ban et al., 2014). Therefore, multi-factor studies are a more adequate framework for investigating the relative weight of the different natural and anthropogenic factors (Davidson \& Knapp, 2007).

Some invasive species have been identified as a cause of large impacts on the receiving ecosystems by direct predation on native species (Simberloff et al., 2013). Previous studies of the effects of invasive species in freshwater ecosystems have shown strong negative ecological consequences (Vitule et al., 2009). Freshwater fishes are amongst the animal groups with the greatest number of invasive species, as has been shown in Europe (Hulme et al., 2009). At present, the introduction of freshwater fishes is closely related to human activities, and particularly with angling, in the case of salmonid fishes (Cambray, 2003).

\section{Introduced fish effects in high mountain lakes}

High mountain lakes are found in remote headwaters, far from populated areas, and may support unique plant and animal communities and hence have tremendous ecological and environmental value (Kernan et al., 2009). Many of them are situated within protected areas with scenic, ethnographic, biodiversity and conservation interest, and varying levels of protection from the most basic to highly protected areas (Wiley, 2003). Although high mountain lakes are often perceived to be pristine, they have been threatened by global stressors such as climate change and by long-distance atmospherically transported pollution including acid deposition, persistent organic pollutants and trace metals (Davidson \& Knapp, 2007; Catalan et al., 2013), which cannot be managed at local scale (Brown et al., 2013). Nevertheless, their major direct anthropogenic stressors are likely to be the introduction of invasive fish stocks (Wiley, 2003) even in traditionally managed mountain landscapes (Denoël et al., 2019), which are managed directly by local or regional administration or civil organizations (Brown et al., 2013).

High mountain lakes are naturally fishless due to natural barriers that have prevented the colonisation of fish species from lower elevation streams. However, there have been numerous trout introductions to such ecosystems around the world since the 19th century, mainly for angling. These introductions have been reported in mountain ranges such as the Rocky Mountains and Sierra Nevada in western North America, the 
Tatras, the Alps, Cantabric range and Sistemas Central and Ibérico in Europe, or the Canterbury high elevation plains in the South Island of New Zealand (e.g. Martinez-Solano et al., 2003; Wiley, 2003; Tiberti \& Splendiani, 2019). Moreover, since the 1900s, minnows have also been introduced to some mountain areas as live-bait for recreational fishing, for example in the north European lakes of Scotland and Norway (Maitland \& Campbell, 1992; Museth et al., 2007).

Several studies since the 1980s have investigated the effect of introduced trout on a range of autochthonous species or assemblages of high mountain lakes worldwide, using data from a large number of sites. They have found that introduced trout becomes the top predator of high mountain lake ecosystems, leading to profound ecological changes. These include the drastic reduction or elimination of amphibian and reptile populations (e.g. Knapp, 2005; Orizaola \& Braña, 2006), changes in zooplankton and benthic macro-invertebrate species composition and size structure (e.g. Knapp et al., 2001; De Mendoza et al., 2012; Tiberti et al., 2014), large-scale alteration of ecosystem processes such as planktonic food web or nutrient cycling (Sarnelle \& Knapp, 2005) and indirect effects on surrounding habitats through resource depletion (Epanchin et al., 2010). Furthermore, the impact of invasive trout on the amphibians of high mountain lakes can be exacerbated by interaction with other stressors, such as airborne pesticides (Davidson \& Knapp, 2007). The negative effect of introduced fish on amphibians is particularly worrying, since they have decreased globally in recent decades, and are one of the most threatened animal groups worldwide (Beebee \& Griffiths, 2005).

\section{Pyrenean high mountain lakes and ponds}

The Pyrenees comprise a continuous high mountain biogeographic area situated in the south west of Europe, running from the Atlantic ocean to the Mediterranean sea $\left(2^{\circ} 05^{\prime} \mathrm{W}-3^{\circ} 15^{\prime} \mathrm{E}, 43^{\circ} 18^{\prime}\right.$ $\left.42^{\circ} 16^{\prime} \mathrm{N}\right)$. There are approximately $4500 \mathrm{high}$ mountain lakes and ponds, all of which are potentially suitable habitats for freshwater organisms. These lakes have been well-studied since the late nineteenth century (e.g. Jeanbernat, 1874), and especially during recent decades. Work has focused on describing their main environmental and ecological characteristics (Kernan et al., 2009) and studying their role as sentinels of global change (e.g. Catalan et al., 2006, 2013). Contrasting with these extensive studies of lakes, the ecological characteristics of ponds have received lower attention.

There have been many studies of the faunal communities of Pyrenean high mountain lakes and ponds, for example zooplankton, zoobenthos and macroinvertebrates are well studied at Pyrenean range scale (e.g. Catalan et al., 2009; De Mendoza et al., 2012). There are six widely distributed amphibians in Pyrenean lakes or ponds across most of the mountain range (e.g. Pleguezuelos et al., 2002). These comprise three anurans: the common frog, Rana temporaria Linnaeus 1758 living in both lakes and ponds, the midwife toad, Alytes obstetricans (Laurenti, 1768) with two subspecies, A. o. obstetricans more frequent in the western range and $A$. $o$. almogavarii in the east, and the common toad, Bufo spinosus Daudin, 1803; and three caudates: the Pyrenean newt, Calotriton asper (Dugès, 1852), an endemic species of the Pyrenees and surrounding areas, the palmate newt, Lissotriton helveticus (Razoumowsky, 1789) and the fire salamander, Salamandra salamandra (Linnaeus 1758). In addition, the Pyrenean frog, Rana pyrenaica Serra-Cobo, 1993 is a recently discovered endemic frog found in some streams of the central Pyrenees. Although Pyrenean amphibian distribution is generally well known, there is also the need of carrying out ecological studies of the assemblage performed at the whole biogeographical region.

\section{Conservation status of Pyrenean high moun- tain lakes}

Most Pyrenean lakes are protected through inclusion within the European Natura 2000 network, and different National or Natural Parks. The lakes as habitats are included in the Habitats Directive, as well as three of the six amphibian species present ( $R$. temporaria, A. obstetricans and $C$. asper). The species' conservation status is classified as Near Threatened (C. asper) or Least 
Concern (the rest) by the IUCN and they are all protected by national and regional laws. High mountain lakes should be preserved due to their associated flora and fauna (threatened in some cases), their strong ecological interest, and their conservation value (Ventura et al., 2017).

Species distributions do not follow political borders but environmental features or gradients; therefore identification of Pyrenean scale problems can aid environmental managers in improving management policies and, therefore, the conservation of these ecosystems. At present there are six different countries or regions that have environmental responsibilities in the Pyrenean range: in general, the northern side is part of France and the southern is part of the Spanish regions of Basque Country, Navarre, Aragon and Catalonia, with Andorra in the south-east. Therefore, there is a strong heterogeneity of protection agencies and environmental management policies across the range. A regional overview of Pyrenean conservation status provides a sound basis for conservation policies and actions at mountain range scale, removing artificial borders and involving all countries and administrations present.

The two main types of threats to Pyrenean high mountain lakes are diffuse pollution, and local stressors such as fish introduction or water level alteration for hydroelectricity. After many studies have described the presence of different types of airborne pollutants in the Pyrenees (e.g. Bartrons et al., 2012), there is ecological and conservation interest for describing the distribution and effects of invasive fish on lake ecosystems across the whole range. Previous studies have suggested that most fish introductions are relatively recent (Sostoa \& Lobón-Cerviá, 1989). Trout species introduced include Salmo trutta Linnaeus, 1758, Oncorhynchus mykiss (Walbaum, 1792) and Salvelinus fontinalis (Mitchill, 1814 ) in the southern (Spanish) Pyrenees (Sostoa \& Lobón-Cerviá, 1989) and these species together with Salvelinus alpinus (Linnaeus, 1758) and Salvelinus namaycush (Walbaum in Artedi, 1792) in the northern (French) Pyrenees (Delacoste et al., 1997). Moreover, the presence of minnows (Phoxinus sp.) in Pyrenean high mountain lakes has also been reported, probably associated with their use as live-bait for recreational fishing (Lobon-Cervia et al., 1989).

This paper summarizes an exhaustive investigation of the historical and ecological factors of fish introduction and their ecological consequences in Pyrenean high mountain lakes (Miró, 2016). The general aim was to describe the magnitude and impact of fish introductions across the whole of the Pyrenees. For that reason, and because previous studies have shown that the most conspicuous animal groups (see above) are those most affected by fish introductions, we

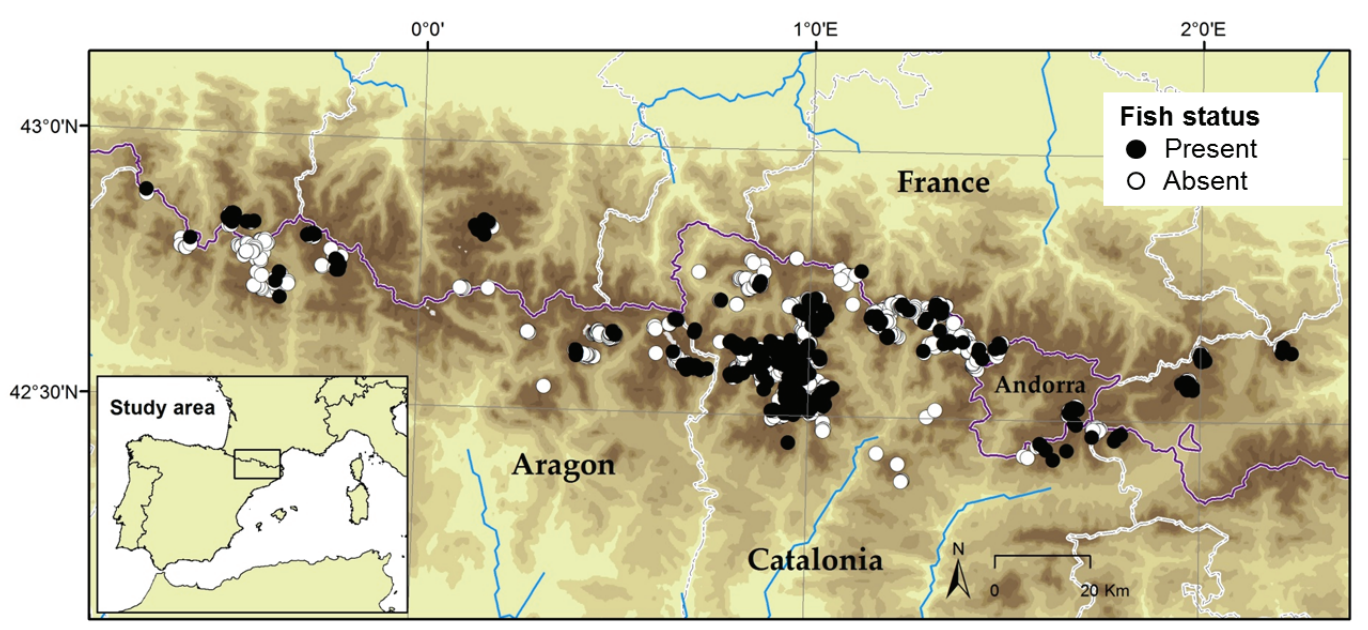

Figure 1. Map of the studied lakes along the Pyrenean range with the presence or absence of fish. Mapa de los lagos estudiados en la cordillera Pirenaica, ilustrando la presencia o ausencia de peces. 
focussed on amphibians and conspicuous macroinvertebrates from the littoral zone, and planktonic crustaceans (the largest and major natural animal group of the pelagic habitat). Finally, we also aimed to study the effect of the trophic cascade on the littoral epilithic community via fish predation of tadpole grazers. Such studies, analysing the effects of different stressors together with environmental factors on ecosystems, can be helpful to inform appropriate management and conservation policies (Hart \& Calhoun, 2010).

\section{METHODS}

To reconstruct the fish introduction process in the Pyrenean lakes, we collected data on trout and minnow occurrence from 520 high mountain lakes $>0.5$ ha which comprise all those lying within the Catalan-Aragonese (Spanish or southern) Pyrenees $\left(0^{\circ} 42^{\prime} \mathrm{W}-2^{\circ} 09^{\prime} \mathrm{E}, 42^{\circ} 52^{\prime}-42^{\circ}\right.$ $23^{\prime} \mathrm{N}$; Fig. 1). This information was obtained from historical documents (period before 1900), from interviews with local elderly fishermen or nature reserve guards, from local reports of fishing or walking societies (period 1900-2000) and from our own visual encounter surveys (period 1980-2000). In few cases, we validated these data by using gill nets. A detailed description of methods can be found in Miró (2016). Then, to investigate the main drivers of fish species occurrence, we compared the presence/absence data with different environmental variables including lake characteristics, site location variables, mode of introduction variables and fish management practice descriptors. We used generalized additive models (GAM) for the analyses because they are similar to generalized linear models, but relax the assumption that the relationships between the dependent variable (when transformed to a logit scale) and predictor variables are linear by estimating a nonparametric loess smooth function for each continuous predictor variables (Hastie \& Tibshirani, 1990; Knapp, 2005). The analysis was run first to obtain a historical perspective every decade from 1900 until present (year 2000) with all the taxa together and secondly with the present day data for each species separately (Miró \& Ventura, 2013, 2015).
To investigate the effect of introduced fish on lake ecosystems, we sampled from 75 to 1736 Pyrenean high mountain lakes and ponds depending on the animal group or epilithic community. We collected data on amphibian and planktonic crustacean species (1736 and 69 sites, respective1y), conspicuous macroinvertebrate taxa (Gerridae, Notonectidae/Corixidae, Odonata, Coleoptera, Trichoptera and Mollusca; 388 sites), and littoral epilithic community (75 sites), as response variables. We also collected fish presence and several environmental lake characteristics as predictor variables: altitude, surface area, conductivity, accumulated temperature, littoral slope, shore habitat, percentage of aquatic vegetation, presence of predation refuge and number of ponds in the terrestrial adjacent area. Then we applied different multivariate and univariate statistical techniques. A detailed description of methods can be found in Miró (2016).

Redundancy analysis (RDA; Wollenberg, 1977) was used to identify the main structures explained by the measured environmental and fish variables on amphibian assemblage. To search for parsimony and prevent the problem of inflation of the overall type I error, before all RDA analyses we performed an appropriate variable forward selection process using a double stopping criterion for each candidate variable: (a) traditional significance level $\alpha=0.05$ and (b) global adjusted $R^{2}$ threshold of the RDA made with all potential explanatory variables, only if that test was significant (Blanchet et al., 2008). In addition, we examined for linear dependencies among the explanatory variables in the RDA using Variance Inflation Factor (VIF, Borcard et al., 2011). We tested the significance of all RDAs and their axes through permutation tests with 999 permutations. To visualize RDA results we drew a correlation triplot diagram (Legendre \& Legendre, 1998), plotting the two most explanatory canonical axes. The site scores were drawn as linear combinations of explanatory variables to avoid excessive overlap that was otherwise found when we used weighted sums of taxa due to the same combination of taxa occurring at several sites.

The impact of introduced fish on the richness of amphibians, conspicuous macroinvertebrates and planktonic crustaceans was assessed by com- 
puting several one-way ANOVA with Tukey post-hoc tests $(\alpha=0.05)$. $\beta$ diversity for diatom assemblage from epilithic community was assessed by computing the distances of the group members to the group centroid (spatial median) in a principal coordinate space (Anderson et al., 2006). The effects of the factors were explored through analyses of the multivariate dispersion (variance), testing by ANOVA the differences between-categories for the distances of the category members to the category centroid. Factors comprised Fish (Yes and No, N = 2) and Tadpole (Yes and No, $\mathrm{N}=2$ ). The similarities among sites used were the Euclidean distances among sites based on the taxonomic matrices normalized through Hellinger transformations (Legendre \& Gallagher, 2001).

Before running the analyses, we transformed continuous variables to bring them closer to the normal distribution when necessary. All variables introduced to RDAs were standardized to zero mean and unit variance to correct their heterogeneous dimensions (Borcard et al., 2011). Binary variables of presence/absence were used directly as dummy (1/0) variables (Legendre \& Legendre, 1998). All analysis were computed with R statistical software (R Core Team, 2016) using the basic functions and the packages packfor (Dray et al., 2013) and vegan (Oksanen et al., 2018).

\section{RESULTS AND DISCUSSION}

\section{Traditional and modern stocking of Pyrenean lakes}

Fish stocking in Pyrenean high mountain lakes is an old practice that has increased during the last half of the $20^{\text {th }}$ century. We found that traditional exploitation dated back at least to the 14th and $15^{\text {th }}$ centuries. These initial introductions affected $26.5 \%$ of the lakes, which already had introduced trout by 1900 (Fig. 2A). However, since 1950 a wave of introductions with exotic species has affected $35 \%$ to $85 \%$ of the Pyrenean lakes, depending on the valley, similar to many other mountain ranges worldwide. The most widespread fish species at the end of the 20th century in the southern Pyrenean slope was S. trutta, which was found in $49.6 \%$ of the lakes. The north
American native species $O$. mykiss and S. fontinalis were also found in $6.2 \%$ and $6.3 \%$ of the lakes, respectively (Fig. 2A; Miró \& Ventura,

A) Fish introduction process $20^{\text {th }}$ century

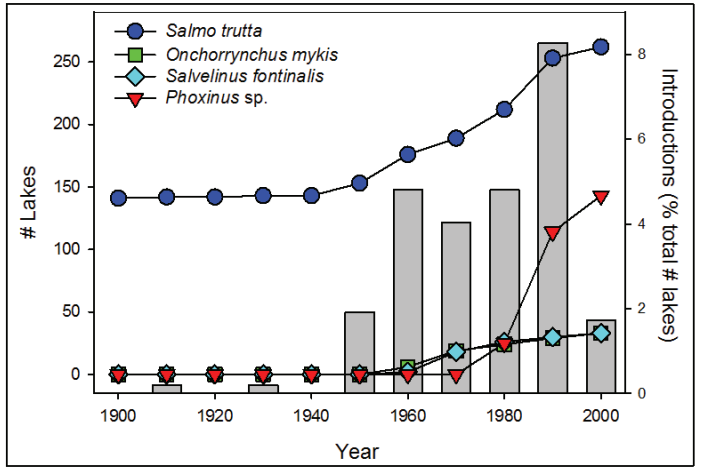

B) Variable importance in GAM analyses

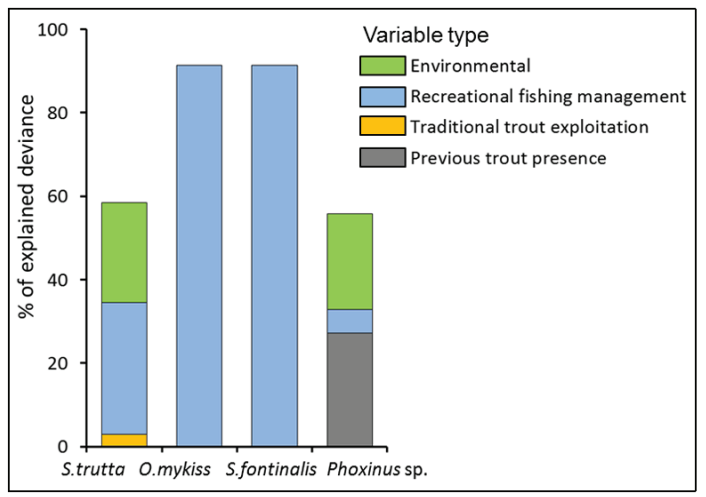

Figure 2. Left panel (A): Introduction process of non-native trout and minnows in the southern Pyrenees during the twentieth century (reprinted from Miró \& Ventura (2013) with permission from Elsevier). Vertical grey bars are the decadal total number of lakes that have suffered fish introductions in percentage of the total number of lakes $>0.5$ ha of the study area $(n=520)$. Right panel (B): Relative importance of the different types of variables affecting fish introductions in the southern Pyrenean lakes, showed by GAM models. Only the deviance increase explained by the variables is plotted (see the text and Miró \& Ventura (2013) for further details of the analyses). Panel izquierdo (A): Proceso de introducción de truchas y piscardos alóctonos en la vertiente sur de los Pirineos durante el s. XX (reproducido de Miró \& Ventura (2013) con permiso de Elsevier). Las barras grises verticales indican el número de lagos en que se han hecho introducciones en cada década, en porcentaje sobre el número total de lagos $>0.5$ ha del área de estudio $(n=520)$. Panel derecho $(B)$ : Importancia relativa de los distintos tipos de variables que explican las introducciones de peces alóctonos en los lagos de la vertiente sur de los Pirineos, obtenidas en los modelos GAM. Se muestra el incremento de devianza explicada por las variables (ver texto y la referencia Miró \& Ventura (2013) para conocer los análisis en detalle). 
2013). Our findings suggest that human exploitation of some of these lakes might have originated further back in time, possibly to the Neolithic, when primitive residents already used the high altitude pastures. However, the written evidences suggest that the first major historical introductions occurred within the medieval warm period (1000-1300 AD) when the human population in the Pyrenees was at its highest density.

This result contrasts with most of the available literature for other mountain ranges across the world, where trout introductions are relatively recent. In North America, introductions started in the 19th century with the arrival of European colonists (Wiley, 2003) and in most of Europe it was not until the end of the $19^{\text {th }}$ and $20^{\text {th }}$ centuries that most alpine areas were populated with trout (Sostoa \& Lobón-Cerviá, 1989; Wiley, 2003; Denoël et al., 2019).

The existence of traditional fishing rights for local citizens in the Pyrenees, as described in the historical written documents (Miró, 2011), probably contributed strongly to lake stocking in historical periods. In addition, lakes traditionally used for fishing were typically closer to towns and hence easier to exploit, were at lower altitude, and had higher surface areas. Our results clearly support this hypothesis. The distribution of $S$. trutta was best explained by both anthropogenic factors and lake characteristics, while only anthropogenic factors were associated with the distribution of $S$. fontinalis and O. mykiss (Fig. 2B). The data from 1900 to 1950 showed that walking distance from nearby urban centres was the dominant factor explaining $29-60 \%$ of the variation in trout distribution. In contrast, for the period 1960-2000, the most significant factors were management practices associated with modern recreational fishing, and lake characteristics likely to be related to the probability of survival of the fish populations. These results are similar to those found in other areas of the world, including mountain areas of the western USA, where trout species are present in $c a .60 \%$ of lakes (Wiley, 2003). Furthermore, a fishing ban in protected areas has resulted in a stabilization of the number of lakes with trout or minnows, suggesting that this is a reliable management policy for avoiding new introductions and preserving the conservation status of high mountain lakes (Miró \& Ventura, 2013).

In recent decades, minnows have also been introduced to some mountain areas, including the Pyrenees, a process associated with their use as live-bait for recreational fishing. Our results strongly support that the introduction of minnows to the high mountain lakes of the Pyrenees is mediated by a preceding invasive species and facilitated by human activity (Miró \& Ventura, 2015; Miró, 2016). We found that the introduction of minnow is a more recent and more rapid process than that of salmonids. Since 1970s, when the first introduction took place, it has now spread to $27 \%$ of the lakes of the southern Pyrenees with an introduction rate of 4.7 lakes per year, compared to 2.2 lakes per year for trout over the period between 1940 and 2000 (Fig. 2A; Miró $\&$ Ventura, 2015).

Our results also indicate that the presence of trout before minnow introduction is by far the most important variable explaining minnow distribution (Fig. 2B). In fact, we have not found any case of minnow introduction in naturally fishless lakes, strongly supporting the hypothesis that recreational fishing with live-bait is responsible for these introductions in high mountain lakes of the Pyrenees. Unlike trout, minnow introductions are in general not authorised by governmental authorities and their introduction is often an illegal angling practice. In many cases fish unused as live-bait are released at the end of the fishing expedition (Maitland \& Campbell, 1992), which makes their spread more difficult to control.

Another concerning aspect is that the minnow, like other small widely-distributed freshwater fish, displays a remarkable variability in its life history depending on the site temperature. For example, minnows have a maximum life-span of between 3 and 13 years, and the age of maturity varies from $1-2$ to 5-7 years in hot and cold places, respectively, while showing significantly lower growth increments in cold summers (Mills, 1988). This plasticity in their life history is an important factor in the species' ability to easily adapt from living in streams, its natural habitat, to high mountain lakes, where it shows higher resistance to harsh conditions than trout. In fact, in the Pyrenees we have found that in 8 lakes (and 12 ponds) pre-existing 
A) Amphibians

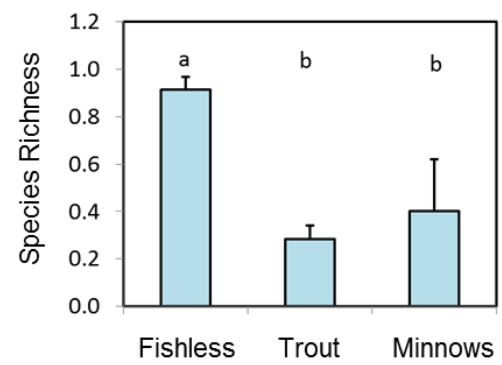

B) Conspicuous macroinvertebrates

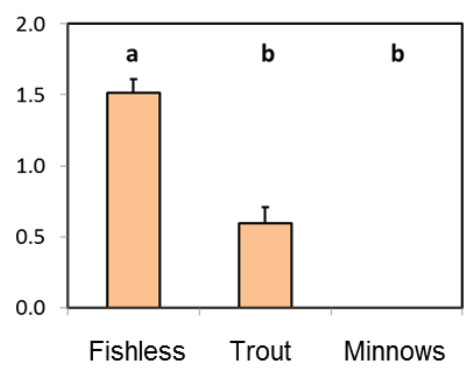

C) Planktonic crustaceans

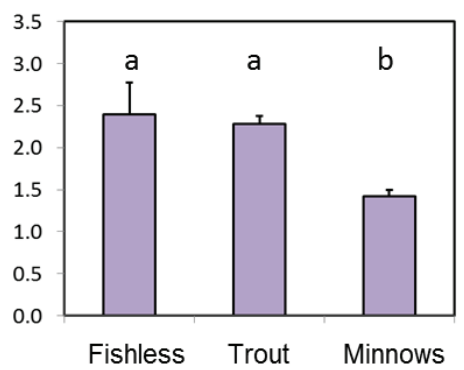

Figure 3. Taxonomic richness of amphibians (A), conspicuous macroinvertebrates (B) and planktonic crustaceans (C) in a subset of 69 lakes and ponds. Letters indicate significant different groups at the one-way ANOVA Tukey post-hoc analyses. Error bars show the $\mathrm{SE}$ of the mean. The sizes of the categories were: Fishless, $\mathrm{n}=46$; Trout, $\mathrm{n}=13$; Minnows, $\mathrm{n}=10$. Riqueza taxonómica de anfibios (A), macroinvertebrados más conspicuos (B) i crustáceos planctónicos (C) en un conjunto de 69 lagos y estanques. Las letras minúsculas indican grupos significativamente distintos determinados mediante un análisis ANOVA Tukey post-hoc de una via (P < 0.05). Las barras de error indican el error estándar de la media. El tamaño muestral de las categorías fue: Fishless, $n=46 ;$ Trout, $n=13$; Minnows, $n=10$.

trout populations have disappeared after minnow introductions. In some of these lakes brown trout were introduced centuries ago, while others were stocked more recently. Although in some lakes trout might have disappeared due to the lack of suitable reproductive areas or other environmental factors, in other lakes such as those described above, minnow introduction are likely behind trout disappearance. Minnows compete with trout for resources (Borgstrøm et al., 1996), and also predate on trout eggs, reducing trout recruitment, that altogether with fishing reduces trout abundance until they disappear.

\section{Introduced fish invasiveness in Pyrenean lakes}

Fish introduced in Pyrenean high mountain lakes, both trout and minnows, are invasive species. The results obtained clearly show a large impact on the Pyrenean lake biota (Miró, 2016). We demonstrated that the impact of trout on Pyrenean high mountain lake fauna is clear and similar to that found in the lakes of other mountain ranges. Trout was the most important factor determining the presence of amphibians and conspicuous macroinvertebrates in the lakes, as well as the taxonomic richness of both assemblages (Figs. 3 and 4).

At taxon level, the presence of trout has stronger impacts on amphibian and conspicuous macroinvertebrate taxa occurrence than on plank- tonic crustaceans (Fig. 3; Ventura et al., 2016). Our findings are, in general, consistent with the results of previous studies on salmonid impact on high mountain lakes. Strong effects of trout on some amphibians and macroinvertebrates have also been found in several mountain ranges of the US and Europe (Knapp et al., 2001; Knapp, 2005; Orizaola \& Braña, 2006; De Mendoza et al., 2012; Tiberti et al., 2014).

Minnows had similar impacts to trout on the littoral fauna, but greater impacts on the planktonic crustaceans (Fig. 3; Ventura et al., 2016). Our results showed a strong impact on amphibian and conspicuous macroinvertebrate richness similar to the impact showed by trout. Although there are few studies available evaluating the impact of minnows on amphibians and macroinvertebrates of high mountain lakes, minnow species have been shown to negatively affect these organisms in lowland and boreal lakes (e.g. Werner et al., 2007). Minnows have also been reported as a cause of declines of frogs, paedomorphic newts and the species richness of amphibian tadpoles (Denoël et al., 2005; Werner et al., 2007).

In contrast with trout, minnows also affect the occurrence of some planktonic crustaceans, mainly the largest species, but only when minnows are the only fish in the lake. In fact, when trout is also present, minnows live in the 
A) Amphibian occurrence

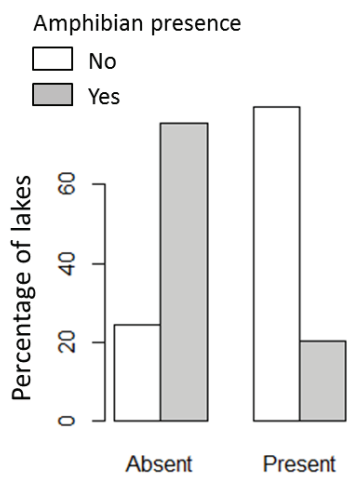

Introduced fish
B) Redundancy analysis for amphibian assemblage

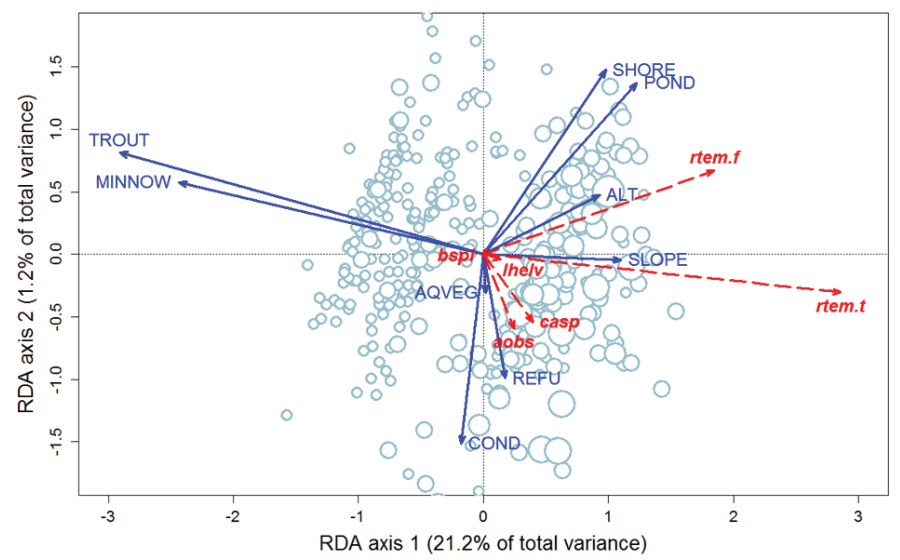

Figure 4. Left panel (A): Amphibian occurrence in 1736 Pyrenean fish-containing or fishless lakes and ponds. Right panel (B): Redundancy analysis correlation triplot for amphibian assemblage in 388 lakes $>0.5$ ha. Lakes are drawn with circles as site scores (linear constraint scores). Circle size indicates amphibian species richness, between 0 and 5 species (smaller and larger circles, respectively). Taxa name abbreviations are: $R$. temporaria tadpole (rtem.t), R. temporaria frog (rtem.f), A. obstetricans (aobs), B. spinosus (bspi), L. helveticus (lhelv) and Calotriton asper (casp). Name abbreviations of predictor variables are: trout presence (TROUT), minnow presence (MINNOW), percentage of vegetated shore (SHORE), number of ponds in adjacent terrestrial area (POND), altitude (ALT), low littoral slope (SLOPE), predation refuge presence (REFU), water conductivity (COND) and percentage of aquatic vegetation coverage (AQVEG). Panel izquierdo (A): Ocurrencia de anfibios en 1736 lagos Pirenaicos con presencia o ausencia de peces alóctonos. Panel derecho (B): Análisis de redundancia para la comunidad de anfibios de 388 lagos Pirenaicos $>0.5$ ha. Los lagos se han representado como círculos, el tamaño de los cuales indica la riqueza taxonómica de anfibios de 0 a 5 especies (círculos pequeños i grandes respectivamente). Las abreviaciones de especies corresponden a: renacuajos de R. temporaria (rtem.t), adultos de R. temporaria (rtem.f), A. obstetricans (aobs), B. spinosus (bspi), L. helveticus (lhelv) y C. asper (casp). Las abreviaciones de variables corresponden a: presencia de truchas (TROUT), presencia de piscardos (MINNOW), porcentaje de costa con vegetación (SHORE), número de estanques en los alrededores del lago (POND), altitud (ALT), pendiente litoral suave (SLOPE), presencia de refugio de depredación (REFU), conductividad del agua (COND) y porcentaje de superficie litoral con vegetación acuática (AQVEG).

littoral fringe of the lake (Museth et al., 2007), where they are unable to feed on planktonic crustaceans. Our results on planktonic crustaceans are in line with previous studies from high mountain lakes of the Alps (Schabetsberger et al., 1995, 2006). We found that in this interesting interaction between minnows and trout as stressors, trout did not show any single negative impact on planktonic crustacean occurrence, while minnows only showed a negative effect in absence of trout. Actually, the most severe negative effect in terms of Cyclops abyssorum Sars, 1863 and Diaptomus cyaneus Gurney, 1909 occurrence was when minnows were the only fish in the lakes. This finding is consistent with previous studies from Scandinavian boreal lakes where minnows had no impact on zooplankton when trout was also present in the lake (e.g. Larsson et al., 2010). Our research group is currently performing further studies on zooplankton abundance, which will allow testing fish effects on species density apart from presence/absence.

Presence of introduced fish was an important variable explaining the presence/absence of four of the six amphibian species found in the Pyrenean high mountain lakes and ponds, and the most important for R. temporaria (Fig. 4; Miró et al., 2018). However, five of the six amphibian species were more frequent in the western than in the eastern region of the Pyrenees. This appears to be related to spatial patterns of environmental variables. The data from the western Pyrenees identified some natural environmental characteristics in this area that were clearly associated with the higher frequency of amphibians. Significant environmental factors included water conductivity for A. obstetricans, water conductivity together with diurnal water temperature variation (difference 
between daily maximum and minimum water temperature) for $C$. asper and ice-cover duration (a proxy for accumulated summer water temperature; I. Sabas, Pers. Comm.) for B. spinosus.

Finally, we reported the existence of a trophic cascade mediated by introduced fish in the littoral of high mountain lakes, which altered the epilithon community at several levels, including biomass, diversity and the degree of activity or senescence (Fig. 5; Miró, 2016; Ventura et al., 2016). Despite the large top-down influence of introduced fish on the littoral food web of Pyrenean high mountain lakes, the analyses of the relative taxonomic abundances of diatoms and bacteria, showed some bottom-up control through availability of resources. The coexistence of both top-down and bottom-up forces have been described before in the food webs of lakes and ponds (Fitter \& Hillebrand, 2009). However, top-down control has been found to be more important in clear lakes, and in shallow lakes with low coverage of submerged macrophytes (Jeppe- sen et al., 1997), characteristics often observed in high mountain lakes and ponds.

\section{Conservation implications at Pyrenean range}

There is a clear need for improving the conservation status of Pyrenean high mountain lakes and ponds, since $35 \%$ to $85 \%$ of the lakes $>0.5$ ha, depending on the valley, have suffered fish introductions (Miró \& Ventura, 2013, 2015; Ventura et al., 2017). Our results show that the spatial distribution of suitable habitats for the studied freshwater organisms in the Pyrenees is highly fragmented, as a result of both natural and anthropogenic factors such as introduced fish or emerging diseases (especially for particular species such as $A$. obstetricans and $S$. salamandra) (Walker et al., 2010). This fragmentation may lead to loss of fitness through inbreeding or local extinction through stochastic effects (Griffiths \& Williams, 2000). This negative effect may still be stronger on species with a small geographic
A) Algal biomass

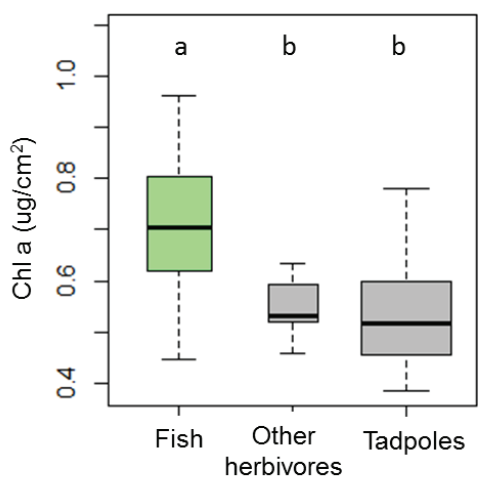

B) Algal groups

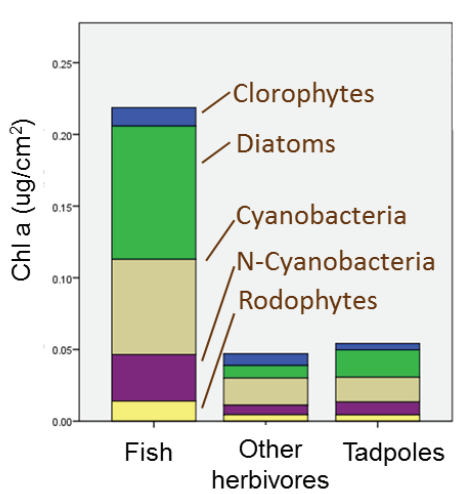

C) Prokaryotes

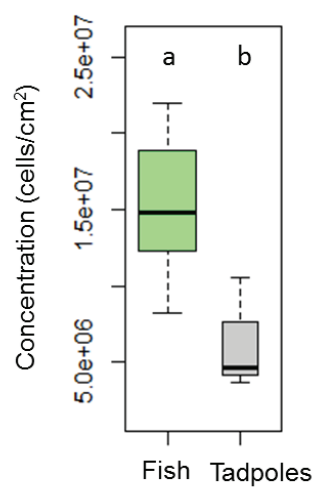

Figure 5. Panel (A): Algal biomass of epilithic communities represented by the concentration of Chlorophyll- $a$ (fourth root transformed) per surface unit of stone. Panel (B): Algal biomass of the main primary producers for each lake type: lakes with non-native fish, lakes with tadpoles and lakes with other grazers. Panel (C): Abundance of prokaryotes (bacteria and archea) on the epilithon of studied lakes and ponds. The letters in (A) and (C) are significantly different groups at the one-way ANOVA Tukey Post-hoc test $(P<0.05)$. In $(\mathrm{B})$ there are no significant differences in the relative composition of algal and cyanobacteria groups, although there are significant differences in their concentration as shown in (A). A subset of 75 lakes and ponds was used. Panel (A): Biomasa algal de la comunidad epilítica representada con la concentración de Clorofila-a (transformada a raíz cuarta) por superficie de piedra. Panel (B): Biomasa algal de los principales productores primarios para cada tipo de lagos: lagos con peces alóctonos, lagos con renacuajos y lagos con otros herbívoros. Panel (C): Abundancia de procariotas (bacteria y archea) en la comunidad epilítica de los lagos y estanques estudiados. Las letras minúsculas en (A) y (C) indican grupos significativamente distintos determinados mediante un análisis ANOVA Tukey post-hoc de una vía $(P<0.05)$. No existen diferencias significativas en $(B)$ para la composición relativa de los grupos algales i cianobacterias, aunque sí existen para sus concentraciones, tal y como muestra el panel (A). Para este análisis se usó un subconjunto de 75 lagos y estanques Pirenaicos. 
distribution range, which should be urgently targeted for conservation (Sodhi et al., 2008), such as $C$. asper, including rare paedomorphic evolutionary units identified (Oromi et al., 2019), or the different subspecies of $A$. obstetricans (Maia-Carvalho et al., 2014).

Restoration of high mountain lake fauna has been shown to be rapid when trout is removed (e.g. Knapp et al., 2007), since high mountain lake fauna have low resistance, but high resilience, to fish introductions (Knapp et al., 2001). Several studies have demonstrated that removal of introduced fish allows rapid recovery of amphibians and macroinvertebrates in the littoral, and also the progressive recovery of the pelagic habitat (e.g. Sarnelle \& Knapp, 2005; Knapp et al., 2007; Denoël \& Winandy, 2015). In addition, an on-going initiative of lake restoration through trout and minnow removal in the Pyrenees (within the framework of the LIFE+ LimnoPirineus project; www.lifelimnopirineus.eu) suggests that high mountain lakes recover some sensitive fauna even before complete fish eradication.

Since the Pyrenees are shared by several countries and regions, there is a high heterogeneity of protection agencies and environmental management policies across the range. Moreover, fish stocking actions are mostly regulated by different agencies from those responsible for conservation policies. In conclusion, we suggest that for implementing a successful conservation policy for Pyrenean high mountain lakes and ponds, conservation planning should be designed at a range scale, transcending political boundaries and incorporating spatial environmental patterns and fish stocking management, as well as adequate restoration actions.

\section{ACKNOWLEDGEMENTS}

The authors thank the Iberian Association of Limnology (AIL) for the award to the best Iberian thesis in the field of limnology 2016-17, and for their invitation to present the research in a plenary talk at the AIL 2018 congress in Coimbra and to contextualize this manuscript. Also, we would like to acknowledge all people who helped us during the field work and the facilities given in the field work by management teams, employees and nature wardens of the Catalan, Aragonese and French environmental public agencies and from the Pyrenean protected areas. Economic support was provided by the Spanish Government projects Fundalzoo (CGL2010-14841), Invasivefish (427/2011). We also benefited from the Biodiversity Conservation Plan from ENDESA S. A. with the project number 6900014499 . This paper is a contribution of the LIFE+ LimnoPirineus project (LIFE13 NAT/ES/001210) and Funbio (RTI2018-096217-B-I00).

\section{REFERENCES}

ANDERSON, M. J., K. E. ELLINGSEN \& B. H. MCARDLE. 2006. Multivariate dispersion as a measure of beta diversity. Ecology Letters, 9 (6): 683-693. DOI: 10.1111/j.1461-0248.2006. 00926.x

BAN, S. S., N. A. J. GRAHAM \& S. R. CONNOLLY. 2014. Evidence for multiple stressor interactions and effects on coral reefs. Global Change Biology, 20 (3): 681-697. DOI: 10.1111/gcb. 12453

BARTRONS, M., J. O. GRIMALT \& J. CATALAN. 2012. Food web bioaccumulation of organohalogenated compounds in high mountain lakes. Limnetica, 31 (1): 155-164.

BEEBEE, T. J. C. \& R. A. GRIFFITHS. 2005. The amphibian decline crisis: A watershed for conservation biology? Biological Conservation, 125 (3): 271-285. DOI: 10.1016/j.biocon. 2005.04.009

BLANCHET, F. G., P. LEGENDRE \& D. BORCARD. 2008. Forward selection of explanatory variables. Ecology, 89 (9): 2623-2632. DOI: 10.1890/07-0986.1

BORCARD, D., P. LEGENDRE \& F. GILLET. 2011. Numerical ecology with R. 3rd edn. Springer, New York, US.

BORGSTRØM, R., J. E. BRITTAIN, K. HASLE, S. SKJØLÅS \& J. G. DOKK. 1996. Reduced recruitment in brown trout Salmo trutta, the role of interactions with minnow Phoxinus phoxinus. Nordic Journal of Freshwater Research, 72: 30-38.

BROOK, B. W., N. S. SODHI \& C. J. A. BRADSHAW. 2008. Synergies among extinction drivers under global change. Trends in Ecolo- 
gy \& Evolution, 23 (8): 453-460. DOI: 10.1016/ j.tree.2008.03.011

BROWN, C. J., M. I. SAUNDERS, H. P. POSSINGHAM \& A. J. RICHARDSON. 2013. Managing for interactions between local and global stressors of ecosystems. Plos One, 8 (6): e65765. DOI: 10.1371/journal. pone. 0065765

CAMBRAY, J. A. 2003. Impact on indigenous species biodiversity caused by the globalisation of alien recreational freshwater fisheries. Hydrobiologia, 500 (1-3): 217-230. DOI: 10.1023/A:1024648719995

CATALAN, J., L. CAMARERO, M. FELIP, et al. 2006. High mountain lakes: extreme habitats and witnesses of environmental changes. Limnetica, 25 (1-2): 551-584.

CATALAN, J., M. G. BARBIERI, F. BARTUMEUS, et al. 2009. Ecological thresholds in European alpine lakes. Freshwater Biology, 54 (12): 2494-2517. DOI: $10.1111 / \mathrm{j} .1365-$ 2427.2009.02286.X

CATALAN, J., S. PLA-RABES, A. P. WOLFE, et al. 2013. Global change revealed by palaeolimnological records from remote lakes: a review. Journal of Paleolimnology, 49 (3): 513-535. DOI: 10.1007/s10933-013-9681-2

DAVIDSON, C. \& R. A. KNAPP. 2007. Multiple stressors and amphibian declines: Dual impacts of pesticides and fish on yellow-legged frogs. Ecological Applications, 17 (2): 587-597. DOI: 10.1890/06-0181

DE MENDOZA, G., E. RICO \& J. CATALAN. 2012. Predation by introduced fish constrains the thermal distribution of aquatic Coleoptera in mountain lakes. Freshwater Biology, 57 (4): 803-814. DOI: 10.1111/j.1365-2427.2012. 02746.x

DELACOSTE, M., P. BARAN, J. M. LASCAUX, N. ABAD \& J. P. BESSON. 1997. Evaluation of salmonid introductions in high-elevation lakes and streams of the Hautes-Pyrenees region. Bulletin Français de la Pêche et de la Pisciculture, 344-45: 205-219.

DENOËL, M., G. DZUKIC \& M. L. KALEZIC. 2005. Effects of widespread fish introductions on paedomorphic newts in Europe. Conservation Biology, 19 (1): 162-170. DOI: 10.1111/j. 1523-1739.2005.00001.x
DENOËL，M. \& L. WINANDY. 2015. The importance of phenotypic diversity in conservation: Resilience of palmate newt morphotypes after fish removal in Larzac ponds (France). Biological Conservation, 192: 402-408. DOI: 10.1016/j.biocon.2015.10.018

DENOËL, M., G. F. FICETOLA, N. SILLERO, et al. 2019. Traditionally managed landscapes do not prevent amphibian decline and the extinction of paedomorphosis. Ecological Monographs: 1-15. DOI: 10.1002/ecm.1347

DRAY, S., P. LEGENDRE \& G. BLANCHET. 2013. packfor: forward selection with permutation (Canoco p.46). $\mathrm{R}$ package version $0.0-8 / \mathrm{r} 109$.

EPANCHIN, P. N., R. A. KNAPP \& S. P. LAWLER. 2010. Nonnative trout impact an alpine-nesting bird by altering aquatic-insect subsidies. Ecology, 91 (8): 2406-2415. DOI: 10.1890/09-1974.1

FITTER, A. \& H. HILLEBRAND. 2009. Microbial food web structure affects bottom-up effects and elemental stoichiometry in periphyton assemblages. Limnology and Oceanography, 54 (6): 2183-2200. DOI: 10.4319/10.2009.54.6.2183

GRIFFITHS, R. A. \& C. WILLIAMS. 2000. Modelling population dynamics of great crested newts (Triturus cristatus): a population viability analysis. Herpetological Journal, 10 (4): 157-163.

HART, D. D. \& A. J. K. CALHOUN. 2010. Rethinking the role of ecological research in the sustainable management of freshwater ecosystems. Freshwater Biology, 55: 258-269. DOI: $10.1111 / \mathrm{j} .1365-2427.2009 .02370 . \mathrm{x}$

HASTIE, T. \& R. TIBSHIRANI. 1990. Generalised Additive Models. Chapman \& Hall, London - Weinheim - New York - Tokyo Melbourne - Madras.

HULME, P. E., W. NENTWIG, P. PYŠEK \& M. VILÀ. 2009. DAISIE Handbook of alien species in Europe. Springer, Dordrecht, Netherlands.

JEANBERNAT. 1874. Les lacs des Pyrénées. Bulletin de la Societe d'Histoire Naturelle de Toulouse, 2: 272-330.

JEPPESEN, E., J. P. JENSEN, M. SØNDERGAARD, T. LAURIDSEN, L. J. PEDERSEN 
\& L. JENSEN. 1997. Top-down control in freshwater lakes: the role of nutrient state, submerged macrophytes and water depth. Hydrobiologia, 342/343: 151-164. DOI: 10.1023/A:1017046130329

KERNAN, M., M. VENTURA, A. BRANCELJ, et al. 2009. Regionalisation of remote European mountain lake ecosystems according to their biota: environmental versus geographical patterns. Freshwater Biology, 54 (12): 2470-2493. DOI: 10.1111/j.1365-2427.2009. 02284.x

KNAPP, R. A., K. R. MATTHEWS \& O. SARNELLE. 2001. Resistance and resilience of alpine lake fauna to fish introductions. Ecological Monographs, 71 (3): 401-421. DOI: 10.1890/0012-9615(2001)071[0401: RAROAL]2.0.CO;2

KNAPP, R. A. 2005. Effects of nonnative fish and habitat characteristics on lentic herpetofauna in Yosemite National Park, USA. Biological Conservation, 121 (2): 265-279. DOI: 10.1016/j.biocon.2004.05.003

KNAPP, R. A., D. M. BOIANO \& V. T. VREDENBURG. 2007. Removal of nonnative fish results in population expansion of a declining amphibian (mountain yellow-legged frog, Rana muscosa). Biological Conservation, 135 (1): 11-20. DOI: 10.1016/j.biocon. 2006.09.013

LARSSON, P., H. HANSEN \& L. K. B. HELLAND. 2010. Between-year variations in the development of crustacean zooplankton in the Norwegian subalpine lake vre Heimdalsvatn. Hydrobiologia, 642 (1): 61-70. DOI: 10.1007/ s10750-010-0159-1

LEGENDRE, P. \& L. LEGENDRE. 1998. Numerical ecology. 2nd edn. Elsevier Science, Amsterdam, Netherlands.

LEGENDRE, P. \& E. GALLAGHER. 2001. Ecologically meaningful transformations for ordination of species data. Oecologia, 129: 271-280. DOI: $10.1007 / \mathrm{s} 004420100716$

LOBON-CERVIA, J., B. ELVIRA \& P. A. RINCON. 1989. Historical changes in the fish fauna of the river Duero basin. In: Historical change of large alluvial rivers: Western Europe. Petts G. E. (ed.): 221-232. John Wiley \& Sons Ltd. Chinchester, UK.
MAIA-CARVALHO, B., H. GONCALVES, I. MARTINEZ-SOLANO, et al. 2014. Intraspecific genetic variation in the common midwife toad (Alytes obstetricans): subspecies assignment using mitochondrial and microsatellite markers. Journal of Zoological Systematics and Evolutionary Research, 52 (2): 170-175. DOI: $10.1111 /$ jzs.12048

MAITLAND, P. S. \& R. N. CAMPBELL. 1992. Freshwater fishes of the british isles. Harper Collins, London, UK.

MARTINEZ-SOLANO, I., L. J. BARBADILLO \& M. LAPENA. 2003. Effect of introduced fish on amphibian species richness and densities at a montane assemblage in the Sierra de Neila, Spain. Herpetological Journal, 13 (4): 167-173.

MILLS, C. A. 1988. The effect of extreme northerly climatic conditions on the life-history of the minnow, Phoxinus phoxinus (L). Journal of Fish Biology, 33 (4): 545-561. DOI: 10.1111/j.1095-8649.1988.tb05498.x

MIRÓ, A. 2011. Trout in Pyrenean lakes: Tradition, history and conservation implications (In Catalan). Pagès Editors, Lleida.

MIRÓ, A. \& M. VENTURA. 2013. Historical use, fishing management and lake characteristics explain the presence of non-native trout in Pyrenean lakes: Implications for conservation. Biological Conservation, 167: 17-24. DOI: 10.1016/j.biocon.2013.07.016

MIRÓ, A. \& M. VENTURA. 2015. Evidence of exotic trout mediated minnow invasion in Pyrenean high mountain lakes. Biological Invasions, 17 (2): 791-803. DOI: 10.1007/ s10530-014-0769-z

MIRÓ, A. 2016. Fish as local stressors of Pyrenean high mountain lakes: arrival process and impact on amphibians and other organisms. PhD Thesis. University of Barcelona.

MIRÓ, A., I. SABÁS \& M. VENTURA. 2018. Large negative effect of non-native trout and minnows on Pyrenean lake amphibians. Biological Conservation, 218: 144-153. DOI: 10.1016/j.biocon.2017.12.030

MUSETH, J., T. HESTHAGEN, O. T. SANDLUND, E. B. THORSTAD \& O. UGEDAL. 2007. The history of the minnow Phoxinus phoxinus (L.) in Norway: from harmless 
species to pest. Journal of Fish Biology, 71: 184-195. DOI: 10.1111/j.1095-8649.2007. 01673.x

OKSANEN, J., F. G. BLANCHET, M. FRIENDLY, et al. 2018. vegan: Community Ecology Package. R package version 2.5-1. https:// CRAN.R-project.org/package=vegan.

ORIZAOLA, G. \& F. BRAÑA. 2006. Effect of salmonid introduction and other environmental characteristics on amphibian distribution and abundance in mountain lakes of northern Spain. Animal Conservation, 9 (2): 171-178. DOI: 10.1111/j.1469-1795.2006.00023.x

OROMI, N., E. VALBUENA-UREÑA, A. SOLER-MEMBRIVES, et al. 2019. Genetic structure of lake and stream populations in a Pyrenean amphibian (Calotriton asper) reveals evolutionary significant units associated with paedomorphosis. Journal of Zoological Systematics and Evolutionary Research, 57 (2): 418-430. DOI: $10.1111 /$ jzs. 12250

PLEGUEZUELOS, J. M., R. MÁRQUEZ \& M. LIZANA. 2002. Atlas y libro rojo de los anfibios y reptiles de España. Dirección General de la Conservación de la Naturaleza-Asociación Herpetológica Española, Madrid, Spain.

R CORE TEAM. 2016. R: A Language and Environment for Statistical Computing. R Foundation for Statistical Computing, Vienna, Austria. URL http://www.R-project.org.

SARNELLE, O. \& R. A. KNAPP. 2005. Nutrient recycling by fish versus zooplankton grazing as drivers of the trophic cascade in alpine lakes. Limnology and Oceanography, 50 (6): 2032-2042. DOI: 10.4319/1o.2005.50.6.2032

SCHABETSBERGER, R., C. D. JERSABEK \& S. BROZEK. 1995. The impact of alpine newts (Triturus alpestris) and minnows (Phoxinus phoxinus) on the microcrustacean communities of two high altitude karst lakes. Alytes, 12 (4): 183-189.

SCHABETSBERGER, R., S. GRILL, G. HAUSER \& P. WUKUS. 2006. Zooplankton successions in neighboring lakes with contrasting impacts of amphibian and fish predators. International Review of Hydrobiology, 91 (3): 197-221. DOI: 10.1002/iroh.200610867

SIMBERLOFF, D. 2006. Invasional meltdown 6 years later: important phenomenon, unfortunate metaphor, or both? Ecology Letters, 9 (8): 912-919. DOI: 10.1111/j.1461-0248. 2006.00939.x

SIMBERLOFF, D., J.-L. MARTIN, P. GENOVESI, et al. 2013. Impacts of biological invasions: what's what and the way forward. Trends in Ecology \& Evolution, 28 (1): 58-66. DOI: $10.1016 /$ j.tree.2012.07.013

SODHI, N. S., D. BICKFORD, A. C. DIESMOS, et al. 2008. Measuring the meltdown: drivers of global amphibian extinction and decline. Plos One, 3 (2): e1636. DOI: 10.1371/journal. pone. 0001636

SOSTOA, A. \& J. LOBÓN-CERVIÁ. 1989. Fish and fisheries of the River Ebro: actual state and recent history. In: Historical Change of large alluvial rivers: Western Europe. Petts G. E., H. Möller \& A. L. Roux (ed.): 233-247. John Wiley \& Sons. Chinchester, UK.

TIBERTI, R., A. VON HARDENBERG \& G. BOGLIANI. 2014. Ecological impact of introduced fish in high altitude lakes: a case of study from the European Alps. Hydrobiologia, 724 (1): 1-19. DOI: 10.1007/s10750013-1696-1

TIBERTI, R. \& A. SPLENDIANI. 2019. Management of a highly unlikely native fish: The case of arctic charr Salvelinus alpinus from the Southern Alps. Aquatic Conservation: Marine and Freshwater Ecosystems, 29 (2): 312-320. DOI: 10.1002/aqc.3027

VENTURA, M., T. BUCHACA, D. BUÑAY, et al. 2016. Efecto de la introducción de peces en la conservación de anfibios y crustáceos de lagos de alta montaña. Proyectos de investigación en parques nacionales: 2011-2014, 215-230.

VENTURA, M., R. TIBERTI, T. BUCHACA, D. BUÑAY, I. SABAS \& A. MIRÓ. 2017. Why should we preserve fishless high-mountain lakes? In: Advances in Global Change Research, Vol. 62: High Mountain Conservation in a Changing World. Chapter 8. Catalan J., J. Ninot \& M. Aniz (ed.): 181-205. Springer International Publishing. Dordrecht, Netherlands.

VITULE, J. R. S., C. A. FREIRE \& D. SIMBERLOFF. 2009. Introduction of non-native fresh- 
water fish can certainly be bad. Fish and Fisheries, 10 (1): 98-108. DOI: $10.1111 / \mathrm{j} .1467-$ 2979.2008.00312.x

WALKER, S. F., J. BOSCH, V. GOMEZ, et al. 2010. Factors driving pathogenicity vs. prevalence of amphibian panzootic chytridiomycosis in Iberia. Ecology Letters, 13 (3): 372-382. DOI: $10.1111 /$ j.1461-0248.2009.01434.X

WERNER, E. E., D. K. SKELLY, R. A. RELYEA \& K. L. YUREWICZ. 2007. Amphibian species richness across environmental gradients. Oikos, 116 (10): 1697-1712. DOI: 10.1111/j.2007.0030-1299.15935.x

WILEY, R. W. 2003. Planting trout in wyoming high-elevation wilderness waters. Fisheries, 28 (1): 22-27. DOI: 10.1577/1548-8446(2003) 28[22:PTIWHW]2.0.CO;2

WOLLENBERG, A. 1977. Redundancy analysis an alternative for canonical correlation analysis. Psychometrika, 42 (2): 207-219. 